Winners and Losers during a Deep Economic Crisis: Firm-level Evidence from Indonesian Manufacturing

Short title: The 1998 Crisis and Indonesian Industry

Dionisius Narjoko

Centre for Strategic and International Studies, Jakarta, Indonesia.

dion_ardiyanto@csis.or.id

Hal Hill

Australian National University, Canberra, Australia.

hal.hill@anu.edu.au

October 2006, 11,144 words

Key words: Indonesia, crisis, manufacturing, industrial adjustment

Corresponding author:

Professor Hal Hill

Division of Economics

Research School of Pacific and Asian Studies

Australian National University

Canberra, Australia, 0200

Tel/fax: (61-2) 61253095/61253700

Email: hal.hill@anu.edu.au

- This paper draws extensively and primarily on the work of Narjoko (2006). 
Abstract: What happens to firms during periods of deep economic crisis? Depending on the nature of the crisis, the general effects are well known. But, owing to data availability, there are relatively few detailed firm-level studies. With the aid of an unusually rich data base, this paper investigates the effects of Indonesia's 1997-98 crisis on manufacturing establishments. Consistent with studies of other crisis episodes, foreign ownership and prior export orientation are found to be highly significant determinants of survival and recovery. The effects of firm size are ambiguous. The industry in which firms are located, in particular its factor proportions, is also found to be significant. 


\section{Winners and Losers during a Deep Economic Crisis: Firm-level Evidence from Indonesian Manufacturing}

\section{(1) Introduction}

Deep economic crises have profound effects on firms. But are they uniform, in the sense that all firms contract by approximately the same proportion? Theory and empirical evidence suggest that the effects are uneven. Firms have heterogeneous characteristics, inter alia in terms of history, size, ownership, sales orientation, access to technology, and financial arrangements. Their owners too are diverse, in terms of objective functions and entrepreneurial capacities. Moreover, crises are invariably uneven in their industrial and sector impacts, and sometimes regional concentration.

The nature of crises also vary greatly. Some take the form of mild recessions, more akin to downturns as part of business cycle fluctuations. Others may be deep, entail widespread business collapse, and result in a major shake-out in the corporate world. A crisis connotes some contraction in economic activity, but it may range in duration from ' $V$ ' shaped recovery trajectories to ' $L$ ' shaped protracted stagnations. The trigger for crises can also take many forms, including financial collapse, a sudden fall in the exchange rate, political/regime collapse, or a combination of all these events.

There is a large general literature on the causes and consequences of crises. ${ }^{1}$ Much of this literature is general in nature, and rather infrequently gets 'up close' to offer a detailed and disaggregated examination of effects at the enterprise level. The purpose of this paper is to contribute to our understanding of crisis impacts by investigating the firm-level effects of Indonesia's deep economic crisis of 1997-98, with the aid of a rich and comprehensive data set.

Indonesia is ideally suited to such a study. In the wake of three decades of very rapid economic and industrial growth, the economy contracted sharply, by more than $13 \%$ in 1998 . The contraction was initially triggered by capital flight, which resulted in an extremely sharp fall in the country's exchange rate and a financial sector collapse. These in turn fed into the real sector and also had deep political ramifications, including the demise of the 32-year Soeharto regime. Indonesia's statistical agency, the Central Board of Statistics (BPS) monitored the effects of this crisis in the industrial sector through its annual survey of all manufacturing firms with at least 20 employees. Crucially for the purposes at hand, these enterprises are assigned an identification code which enables them to be monitored over time, and which therefore facilitates the construction of a rich panel data set linking firm outcomes to a range of industrial organization and firm-specific characteristics. We are therefore able to obtain deep insights into the nature of both the crisis impacts and the immediate post-crisis recovery trajectory.

\footnotetext{
${ }^{1}$ See for example Glick, Moreno and Spiegel (2001) and Krugman (2001).
} 
The organization of this paper is as follows. In section 2 we provide background to the study. This includes a summary of the international evidence on adjustment to crises, particularly major events in developing countries. We also briefly describe the Indonesian crisis of 1997-98, and provide some context on the country's rapid industrialization and structure preceding the crisis. Section 3 explains the data sources and how the data base employed in this study was constructed. Our methodology and results are presented in Section 4, based on firm-specific impacts. This section also identifies the key factors explaining inter-firm variations in performance and adjustment. Section 5 sums up, and draws attention to some analytical and policy implications.

\section{(2) The Context: Adjustment to Crises and Indonesian Development}

\section{(2.1) Indonesian industrialization before the crisis $^{2}$}

In the mid-1960s, Indonesia had barely commenced the process of modern industrialization. It then experienced very rapid industrial growth and structural change through to 1997. Annual industrial growth was at least $9 \%$ in all but two of the 27 years, 1970-96. Initially, catch-up and import substitution were the principal drivers. From the mid 1980s, labour-intensive exports became a significant engine of growth. Accompanying this growth was rapid structural change, as the industrial sector evolved from the production of simple consumer goods and basic resource processing to a wide range of manufactures of increasing technological sophistication.

Indonesia's emergence as a significant industrial exporter from the mid 1980s was the result of a highly successful reform program involving the lowering of protection, a more open foreign investment regime, and simplified export procedures, combined with effective macroeconomic and exchange rate management.

The country's industrial ownership patterns are characterized by high levels of ownership concentration, both in the sense of corporate conglomeration and seller concentration. Among major industry groups, these ownership patterns reflect the interplay of history, policy and industrial organization factors. By the mid 1960s, no foreign capital was present, and the 'commanding heights' of the economy were in state hands. The SOE sector continued to be important throughout the Soeharto era. Foreign investment returned to the country from the late 1960s in response to the newly liberal policy regime and generous fiscal incentives. Following the government's policy signals, most FDI initially went into import substituting 'tariff factories'. Then, following the successful 1980s reforms, efficiency-seeking, export-oriented FDI became more important. Notwithstanding the importance of the state and foreign firms,

\footnotetext{
${ }^{2}$ This section draws on Hill (1977).
} 
domestic firms are the major players in Indonesian industry. In the mid 1990s, they accounted for more than $50 \%$ of manufacturing value added in all 2-digit industries except ISIC 38 (fabricated metals, electronics and machinery) and ISIC 39 (miscellaneous manufacturing). They were also the major employer, accounting for almost $80 \%$ of the industrial workforce.

\section{(2.2) Indonesia's economic crisis of 1997-98}

Indonesia's economic crisis of 1997-98 was the most serious among the four East Asian economies. Internationally, it ranks with that of the Philippines in 1985-86, Mexico in 1994-95, and Argentina in 2001. After 30 years of rapid, virtually uninterrupted economic growth the country experienced a deep crisis commencing in the second half of 1997 . Triggered initially by the run on, and subsequent collapse of, the Thai Baht, Indonesia began to experience largescale capital flight, resulting in a sharp depreciation of the Rupiah and deep financial distress. ${ }^{3}$ At the peak of the crisis, the dollar exchange rate had fallen from Rp2,500 to Rp17,500, and credit in the modern financial sector had effectively dried up. In the first half of 1998, there was a loss of macroeconomic control, and inflation on an annualized basis exceeded $100 \%$. The economy contracted sharply from late 1997, by over $13 \%$ in 1998 . The industrial sector declined by a similar order of magnitude.

The economic crisis also precipitated a political crisis, culminating in May 1998 in the end of the 32-year authoritarian Soeharto regime. This created a political and institutional vacuum, heightened social and ethnic tension, and for a period threatened the country's territorial integrity. ${ }^{4}$ Investment, both domestic and foreign, also collapsed. In the six years prior to the crisis, net annual FDI inflows averaged $\$ 2.7$ billion, whereas there were net annual outflows of $\$ 1.4$ billion for the five years after the crisis.

Reflecting its 'twin crises', both economic and political, Indonesia also recovered more slowly than its East Asian neighbours. Growth was negligible in 1999 , but recovered to nearly $5 \%$ in 2000 . For the period 2000-05, growth averaged $4.5 \%$, in contrast to the $7.3 \%$ recorded in the pre-crisis period 1990 96. In the immediate post-crisis period, exports responded significantly to the exchange rate depreciation, with a lag. However, in spite of buoyant commodity prices in the early years of the $21^{\text {st }}$ century, export growth since 1998 has been sluggish, compared to both neighbouring East Asian economies and the country's pre-crisis record (Athukorala, 2006).

\footnotetext{
${ }^{3}$ For detailed analyses of the crisis, see the four-monthly 'Survey of Recent Developments' in the Bulletin of Indonesian Economic Studies. The postscript to Hill (2000) documents the crisis and immediate post-crisis developments, while Temple (2003) offers an interpretation in the context of longer term growth dynamics and vulnerabilities.

${ }^{4}$ East Timor, which had been annexed by Indonesia in 1976, reverted to a UN trust territory in 1999 and subsequently became an independent state.
} 


\section{(2.3) International evidence on adjustment to crises}

As noted crises take many forms, and therefore the international literature on their impacts is also diverse. There are literatures related to the effects of a general contraction in economic activity, as well as specific impacts of a financial crisis and a sharp exchange rate depreciation. Adjustment processes are also affected by the behaviour of particular groups of investors (foreign, state, domestic private, large $\mathrm{v} / \mathrm{s}$ small firms), policy responses to the crisis (eg, whether trade and investment regimes become more or less liberal, the quality of macroeconomic management), and the nature of labour market outcomes.

In the case of the industrial sector, since exchange rates invariably depreciate significantly during a crisis, and since almost all of manufacturing consists of tradable goods, this depreciation should cet par boost competitiveness. However, this mechanism may fail to operate, or its effects may be blunted, for at least five reasons.

First, crises often entail exchange rate volatility, introducing price uncertainty and the possibility that the competitive boost would not be durable, or at least durable enough to induce major new investments. Second, crises are often accompanied by the loss of macroeconomic control, which results in rising inflation, thus nullifying the initial exchange rate advantage. In the limiting case of widespread exchange rate depreciations among a group of countries with very similar export structures, the competitive boosts would be minimal. Related to this are demand conditions in major export markets, a consideration for the East Asian economies given their rapidly growing interdependence (World Bank, 2000, ADB, 2002). Thirdly, for firms which are both import-dependent and domestic-market oriented, the combination of higher input costs and the collapse in domestic demand may render them worse off. For highly import-dependent firms which are also export-oriented (eg, in electronics components, the dominant export of most East Asian economies), the exchange rate impacts are likely to be positive but minimal. But if the share of imported inputs is high and the exchange rate depreciation significantly increases the cost of capital, the beneficial effects of the depreciation may be muted, a point developed by Forbes (2002a). Fourth, in the case of generalized economic and political crisis, other factors may nullify the exchange rate effects. These include widespread financial and corporate collapses, the flight of export-oriented foreign investors, and general security problems (see Kawai et al (2000) in general and Rosner (2000) for the case of Indonesia).

Financial sector effects centre on whether the banking sector remains intact during the crisis, how these institutions allocate credit, and the impact of the crisis on firms' collateralized net worth. A typical feature of crises is increased interest rates, as the monetary authorities seek to defend the exchange rate. In a Stiglitz-Weiss world of asymmetric information, banks have difficulty distinguishing between 'good' and 'bad' loans, and hence they adopt 
excessively stringent lending policies, with rationing according to past performance and easily identified (and securable) collateral. These factors, combined with the possibility of a run on deposits, may cause a 'credit crunch'.

The impact of a financial crisis is likely to differ among firms and countries. ${ }^{5}$ Highly leveraged firms, with a higher proportion of short maturity debt, and which are also exposed to exchange rate risk, are likely to be the most adversely affected (see Claessens et al (2000) for East Asian evidence on this). Firms with established connections to international financial markets are likely to be less severely affected, unless there is a generalized financial crisis. Credit rationing is likely to be more severe for younger and smaller firms. Studies of the impact of financial crises on firms have indeed found that larger firms, especially those which are export-oriented and foreign owned, are more likely to borrow from international financial markets, and therefore are less affected by a domestic financial collapse. ${ }^{6}$

More generally, the literature has examined the relevance of firm heterogeneity in response to major crises, and found it to be a significant factor. $^{7}$ We briefly draw attention to some of these key characteristics, and test them below in this paper.

In the case of size, the usual starting point is the presumption that larger firms might be expected to be more competitive, owing to economies of scale, market power and stronger financial resources. However, this relationship may break down in the face of extreme shocks to the business environment. Small firms may be more flexible and nimble, they are less 'top heavy', and they may be less connected to the collapsing financial sector, and be less heavily indebted. The literature cited in the preceding two paragraphs points to different conclusions, although in the empirics the coefficients are generally not very significant.

There are a number of considerations in the case of ownership. Foreignowned firms should be less affected by a crisis. They have 'deeper pockets', are less connected to the failing domestic financial sector and, with their global market reach and knowledge, they are able to more quickly capitalize on the exchange rate depreciation and to facilitate sales redirection from domestic to export markets. This is hypothesized and demonstrated in a number of studies. ${ }^{8}$ Interestingly, the findings seem to apply independently of

\footnotetext{
${ }^{5}$ See Dwor-Frecaut et al (2000) for evidence on the latter proposition among the East Asian economies.

${ }^{6}$ See for example Kawai et al (2000) on the East Asian economies and Krueger and Tornell (1999) on Mexico.

${ }^{7}$ For general surveys, see Dwor-Frecaut et al (eds, 2000) and Claessens et al (2000).

${ }^{8}$ See for example Blalock and Gertler (2005), Desai et al (2004), Kawai et al (2000), and Ramstetter (1999).
} 
foreign parentage. For example, Fukao (2001) and Urata (2002) show that Japanese companies continued to support their distressed affiliates in the crisis-affected East Asian economies, even though Japan itself was in the midst of a protracted recession.

However, much depends on the host economies' foreign investment climate, and the response to it on the part of foreign investors, especially those which are export-oriented. If the rules of the game are stable and predictable, FDI may well increase, owing to the well-known 'fire-sale' phenomenon, occasioned by financial distress, cheaper asset prices and liberalized entry (Athukorala, 2003; Lipsey, 2001). Conversely, an abrupt change in the institutional environment may lead to increased legal uncertainty and less secure property rights. Moreover, economic nationalism may intensify in the wake of a crisis and an IMF-orchestrated rescue package with heavy conditionality. Thus, community sentiment may be hostile to the notion of foreigners buying assets cheaply, and the investment climate may therefore be nominally open but in practice uninviting. This is especially so in the wake of authoritarian regimes which have been broadly liberal on economic policy but which have stifled dissent. Weak legal regimes will typically compound the difficulties of speedy crisis resolution and they will therefore be unable to protect property rights.

Where there is a significant state enterprise sector, as is the case in Indonesia, the response is difficult to predict as much depends on the government's objective function and its capacity to pursue it in times of crisis. One might expect the government to seek to bail out distressed SOEs. The inefficiencies which frequently characterize these firms may also provide scope for increased productivity if managers are allowed more freedom to profit maximize and to shed excess staff. Conversely, a crisis may diminish the capacity of governments to bankroll these SOEs, particularly if they have signed on to an IMF rescue package.

In the case of sales orientation, export-oriented firms are expected to perform better than domestic-oriented ones. This is principally because the former are able to take advantage of the boost to competitiveness from the sharp exchange rate depreciation. This is particularly so when, as in the East Asian economic crisis, the global economy continued to be buoyant. Using a crosscountry data set, Forbes (2000b) found this to be the case for a range of performance indicators, although larger firms and those with higher debt ratios weakened these effects.

Switching from firm to industry characteristics, firms in labour- and natural resource-intensive industries in a country like Indonesia should be less affected compared to those in capital-intensive industries. Exchange rate movements will be expected to reinforce the country's comparative advantage in these activities, particularly in the case of the high domestic value added resource-based industries. Firms in these industries are also more likely to be export-oriented, and thus be able to adjust more quickly to changing relative 
price signals occasioned by exchange rate changes. By contrast, firms in capital-intensive industries, in which a low-income economy does not typically have a comparative advantage, are more likely to be domestic market oriented, more likely to receive import protection (which was generally lowered during the crisis), and they are more likely to be heavily indebted.

\section{(3) Data}

This study utilizes a rich data set, unusually rich by developing country standards. This is the annual survey of large and medium firms conducted by Indonesia's Central Board of Statistics (BPS, Badan Pusat Statistik). The series is designed to survey all manufacturing establishments employing at least 20 workers. The survey is published as Statistik Industri, but we utilize here the raw data from the unpublished establishment-level data tapes. The data cover the period 1993-2000, that is, what may be broadly termed the precrisis, crisis, and post-crisis periods.

The survey questionnaire covers most operating aspects of these establishments. This includes basic information (ISIC classification, year commenced production, location), ownership (foreign, domestic and government), production (gross output, stocks, capacity utilisation, share of output exported), material costs and various types of expenses, labour (headcount and salary and wages), capital stock and investment, and sources of investment funds. Crucially for our purposes, establishments are identified by a code, which enables them to be traced over time. We are thus able to construct a very rich panel data series, and to examine the behaviour of firms over this period of growth, crisis and recovery. These data constitute the source of information contained in figures and tables in this paper.

While the survey is comprehensive, inevitably there are some gaps in coverage. Three in particular need to be noted. First, as noted, the unit of observation is the establishment, not the enterprise. Thus we cannot detect whether an establishment is a stand-alone operation or is part of a business group..$^{9}$ More broadly, given the importance of business conglomerates and the business-finance nexus, especially in the late Soeharto era, firm behaviour at the time of the crisis could presumably have been influenced by membership of a conglomerate, especially one which was 'palace connected' or linked to an affiliated bank which was in financial distress. Henceforth in this paper, for expositional convenience we use the terms 'firm' and 'establishment' interchangeably, but strictly speaking in all cases we are referring to the latter concept.

\footnotetext{
${ }^{9}$ The extent of multi-plant firms in Indonesia is unknown. However, a recentlyconducted in-house BPS survey suggests that they number about 500 to 1,000 firms out of the more than 15,000 surveyed in the early 2000 s.
} 
A second limitation is that the survey provides some information on firms' debt and leverage, but the details are incomplete. In particular, we lack information on the currency in which the debt is denominated, the nature of the financial institution from which funds were borrowed, ${ }^{10}$ and whether the borrowings were hedged. Finally, we lack high-frequency (monthly or quarterly) data, and therefore have to work with annual series. In practice, of course, the occurrence of the crisis, and firms' adjustment to it, do not neatly correspond to such a time period.

While these data limitations are a feature of most industrial surveys, none is serious enough to significantly limit our analysis, and it is useful to emphasize again that this is one of the better set of industrial statistics in the developing world.

A plant-level unbalanced panel is constructed from 1993 to 2000 . The panel is constructed by matching the plants according to the plant-code variable (PSID). The panel has been cleaned and adjusted for some possible mistakes in data entry, for changes in ISIC, and for variable definitions. An inspection of the raw data indicates mistakes are infrequent and that the entry for PSID is highly consistent over time. The cleaned panel contains around 11,000 to 13,600 plants over the period 1993-2000. The plants in the cleaned panel cover 71 and 60 per cent of manufacturing value added and employment respectively. ${ }^{11}$ Oil and gas refining sectors (ISIC 353 and 354) are excluded. They were included in the survey only in the 1990s and the data quality is still weak.

\section{(4) Results}

\section{(4.1) The aggregate picture}

This section analyzes the impact of the crisis at the industry level. We focus on two aspects: the impact on performance and the impact on firm demographics. The performance measure is real value added $(R V A)$. That is, nominal value added deflated by the wholesale price index (WPI), with the latter measured at the three-digit ISIC level. A range of alternative performance measures - for example real gross output, employment, labour productivity and profitability - could of course be employed, but as shown by Narjoko (2006) the results do not vary significantly.

\section{The impact on performance}

10 For example, whether the institution was on or off-shore, state, private or foreign owned, and whether it was affiliated to a manufacturing enterprise.

${ }^{11}$ See Narjoko (2006) for a detailed description on the data cleaning and adjustment. 
Figure 1 shows that the crisis severely affected the manufacturing industry. The sector was growing rapidly before the crisis, but RVA declined substantially during 1998 and 1999 . It s also evident that the crisis began to affect performance immediately in 1997: RVA growth declined from 20.4 per cent in 1996 to 4.8 in 1997. This is consistent with the impact of the crisis on the general economy (see Hill, 2000). Figure 1 also shows that recovery commenced in 2000 and was reasonably robust, as both the level and growth of $R V A$ began to return to those prevailing in the immediate pre-crisis period. 
Figure 1 RVA growth and index, 1994-2000 (\%, 1993=100)

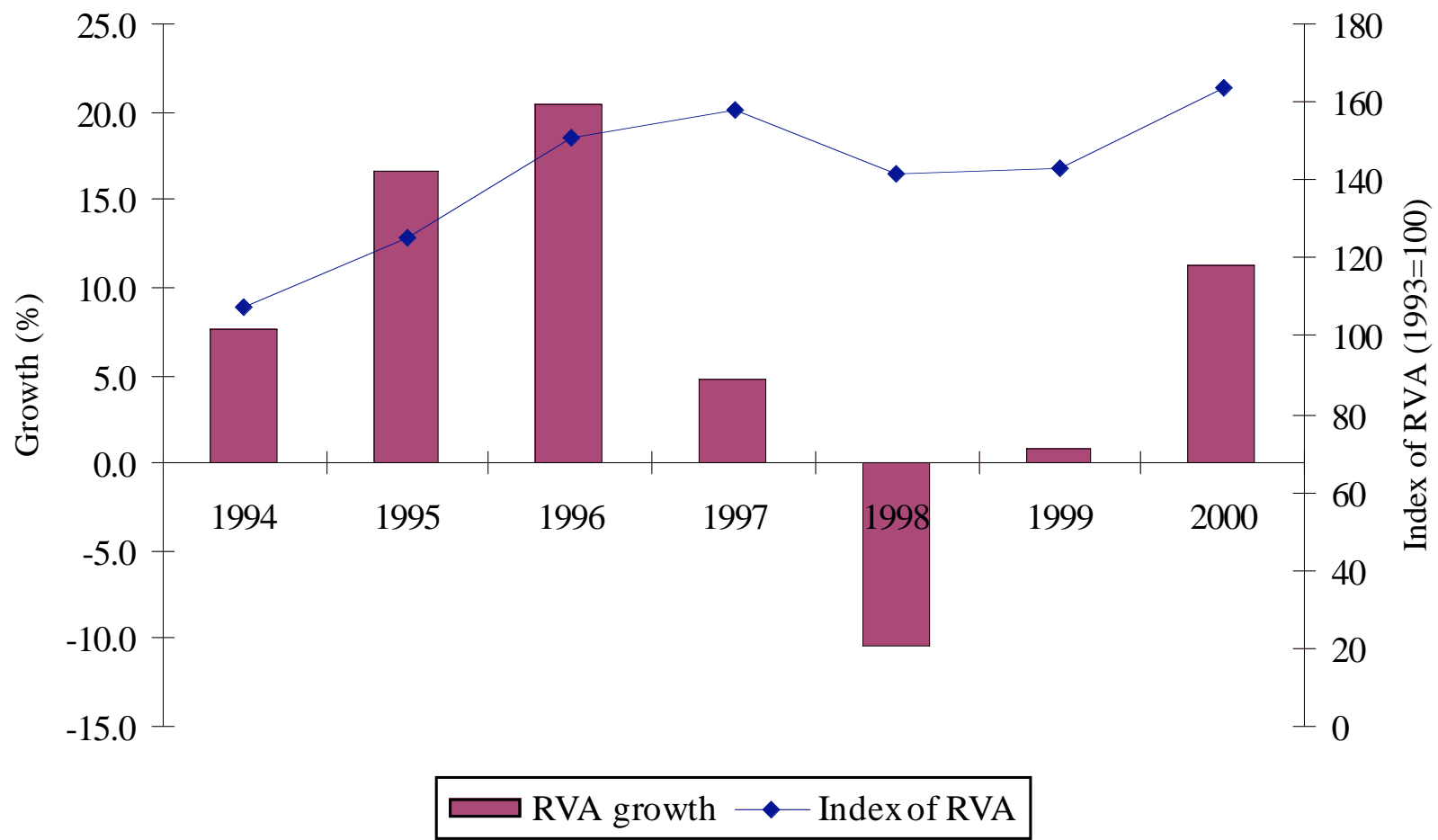

Source: Annual manufacturing survey, BPS.

To obtain a clearer picture of the impact, the percentage difference of $R V A$ between the crisis and pre-crisis period is computed by broad industry group. The difference is formally defined as

$\% \Delta R V A_{j, t}=\frac{R V A_{j, t}-\overline{R V A}_{j, 9596}}{\overline{R V A}_{j, 9596}} \times 100$

where $R V A$ and $j$ denote real value added and industry $j$, respectively. $\mathrm{t}=$ $1997, \ldots, 2000$ and is defined as the crisis period, with subdivisions as noted later. The definition is based on the fact that the crisis began during the fourth quarter of 1997, while recovery got underway from late 1999. It is important to note, though, that the 1997 data present an ambiguous picture, as there was a time lag in order for the crisis to show some negative impact. $R V A_{j, 9596}$ is the average of RVA for the years 1995 and 1996, which we define as the precrisis period.

Table 1 shows that the impact of the crisis differed across industries, a point which has been noted at a general level in previous studies (e.g. Thee 2000; Fukuchi 2000). Some industries actually benefited, notably textiles and garments and particularly wood and paper products (ISIC $32-34$ ), all of which recorded higher positive percentage differences during the peak of the 
crisis compared to its beginning. By contrast, some industries were adversely affected, with the metals and machinery industries (ISIC 37 and 38) recording the largest contractions. There were also pronounced inter-industry variations between years. Output of the wood and paper products industries expanded but growth began to decline, whereas there was a delayed but dramatic recovery in the chemicals and machinery industries (ISIC 35 and 38).

Table 1 Aggregate RVA difference by broad industry group (\%)

\begin{tabular}{|c|l|c|c|c|c|}
\hline ISIC & Industry & 1997 & 1998 & 1999 & 2000 \\
31 & Food and tobacco products & 14.3 & 16.8 & 15.4 & 19.5 \\
32 & Textile, garment and leathers & 8.5 & 30.7 & 18.6 & 24.4 \\
33 & Wood products, including furniture & 8.2 & 58.0 & 33.0 & 31.0 \\
34 & Paper and paper products & 15.7 & 52.0 & 27.5 & 40.0 \\
35 & Chemical, rubber and plastics & 33.2 & 16.3 & 49.2 & 64.2 \\
36 & Non-metallic mineral products & 29.3 & 2.6 & -1.3 & 29.1 \\
37 & Basic metal industries & 22.6 & -74.7 & -69.9 & -63.9 \\
38 & Machinery and equipment & 4.7 & -3.9 & -3.6 & 56.2 \\
39 & Other manufacturing & 39.9 & 86.6 & 44.0 & 52.8 \\
\hline
\end{tabular}

Source: Authors' computation.

Two general observations are warranted. First, industries which are exportoriented seem to have benefited from the crisis. This is clearly shown by the positive performance of textiles, garments and wood products. As indicated in Table 2, the pre-crisis export intensity of these industries is higher than the industry average. Second, the data are suggestive of the role of foreign ownership in influencing recovery trajectories. The two industries which dramatically increased $R V A$ in 2000 (chemical and machinery) have a high share of foreign ownership. Detailed studies of these industries by Thee (2000) and Feridhanusetyawan et al. (2000) show that foreign ownership played a key role in facilitating sales redirection to exports in two major sectors within the broad machinery group, the automotive and automotivecomponent industries. ${ }^{12}$

\footnotetext{
${ }^{12}$ For example, the percentage of cars exported increased from 1.4 in 1997 to 15 in 1998 (Thee 2000, p.432). See also Aswicahyono et al (2000) for discussion of the early response of the automotive industry to the crisis.
} 
Table 2 Selected characteristics of Indonesian manufacturing by broad industry group

\begin{tabular}{|l|l|c|c|}
\hline ISIC Industry & $\begin{array}{c}\text { Export intensity } \\
\text { (\% of value added })\end{array}$ & $\begin{array}{c}\text { Share of } \\
\text { foreign ownership } \\
\text { (\% of value added) }\end{array}$ \\
31 & Food and beverage & 22.2 & 10.4 \\
32 & Textile and garments & 43.8 & 22.6 \\
33 & Wood products, including furniture & 70.0 & 11.0 \\
34 & Paper products & 14.8 & 27.4 \\
35 & Chemical, rubber and plastics & 21.9 & 32.8 \\
36 & Non-metallic mineral products & 11.5 & 19.9 \\
37 & Basic metal industries & 13.7 & 28.6 \\
38 & Machinery and transport equipment & 17.3 & 35.2 \\
39 & Other manufacturing & 52.4 & 54.1 \\
\hline
\end{tabular}

Source: Authors' computation.

The impact on firm demographics

This section investigates the impact of the crisis on firm demographics. On first examination, it appears that the crisis did not severely affect these demographics (Figure 2). The number of firms declined modestly, by just four per cent in 1998, in contrast to the 12 per cent contraction in output. 
Figure 2 Number of plants in Indonesian manufacturing

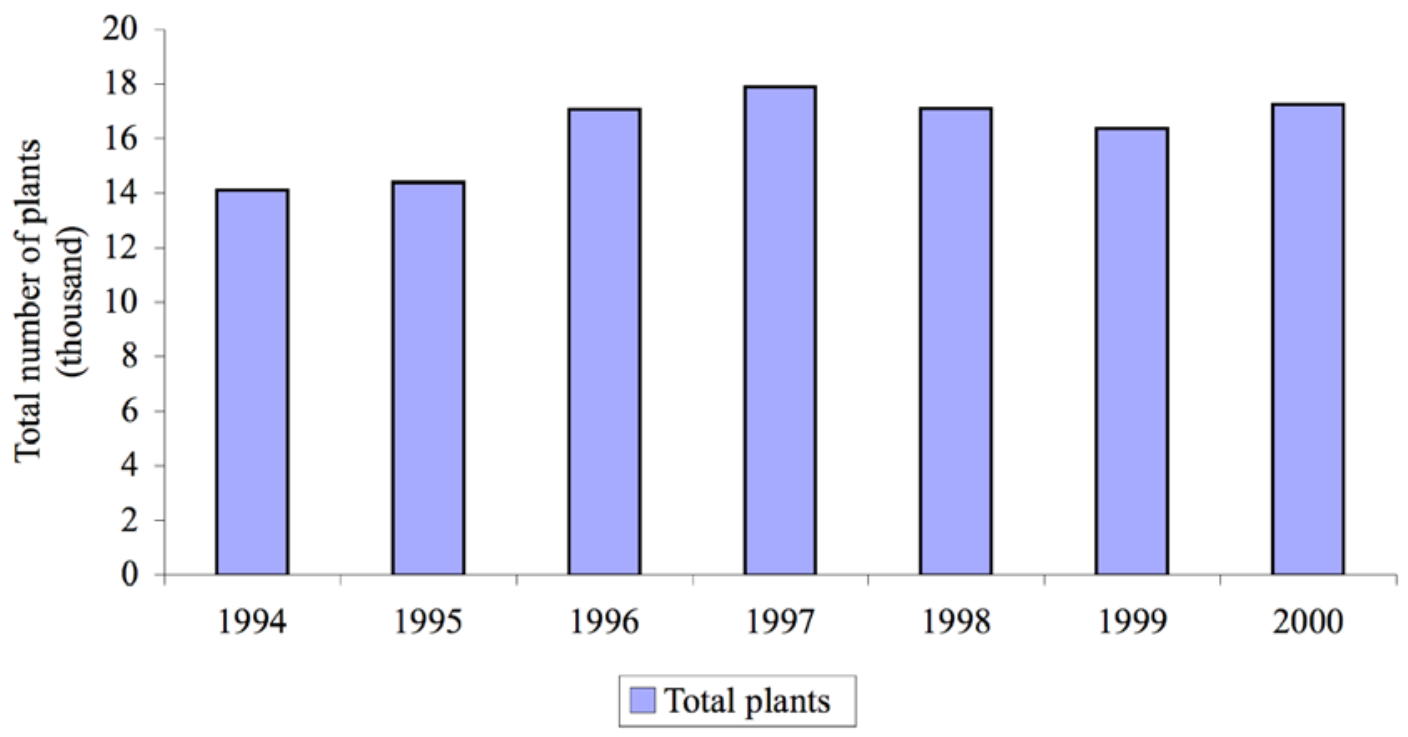

Source: Annual manufacturing survevs. BPS.

However, this does not reveal the full story. We extend the analysis with reference to several other demographic variables, beginning with firm entry and exit. We follow usual practice and define entry and exit rates in terms of the number of plants and employment. Entry and exit rates in terms of number of plants and employment are referred to as EN1 and EX1, and EN2 and EX 2 respectively. Appendix 1 presents a formal definition.

Figures 3 and 4 show trends in both rates in terms of the number of plants and employment respectively. The figures clearly show the dramatic impact of the crisis on firm creation and destruction. In terms of creation, Figure 3 shows that entry rates during the period 1997-2000 fell to about half that during the period 1993-96. The picture is similar if measured by employment (Figure 4), although the magnitude of the decline is slightly lower. Moreover, the rate of creation of firms did not seem to have recovered in 2000 . This is in contrast to the earlier observation that, in terms of $R V A$, industry appeared to have recovered by this year. The decline in entry rates and their sluggish post-crisis recovery could be explained by the lagged response to levels of business confidence. But in addition, the factors governing entry behaviour have been shown to alter during changed business conditions. They are consistent with empirical studies on firm entry (e.g. Highfield and Smiley 1987; Yamawaki 1991) which have found that the determinants of firm entry are sensitive to changes in business cycles.

Figure 3 Entry and exit rates in Indonesian manufacturing in terms of number of plants (EN1 and EX1) (\%), 1994-2000 


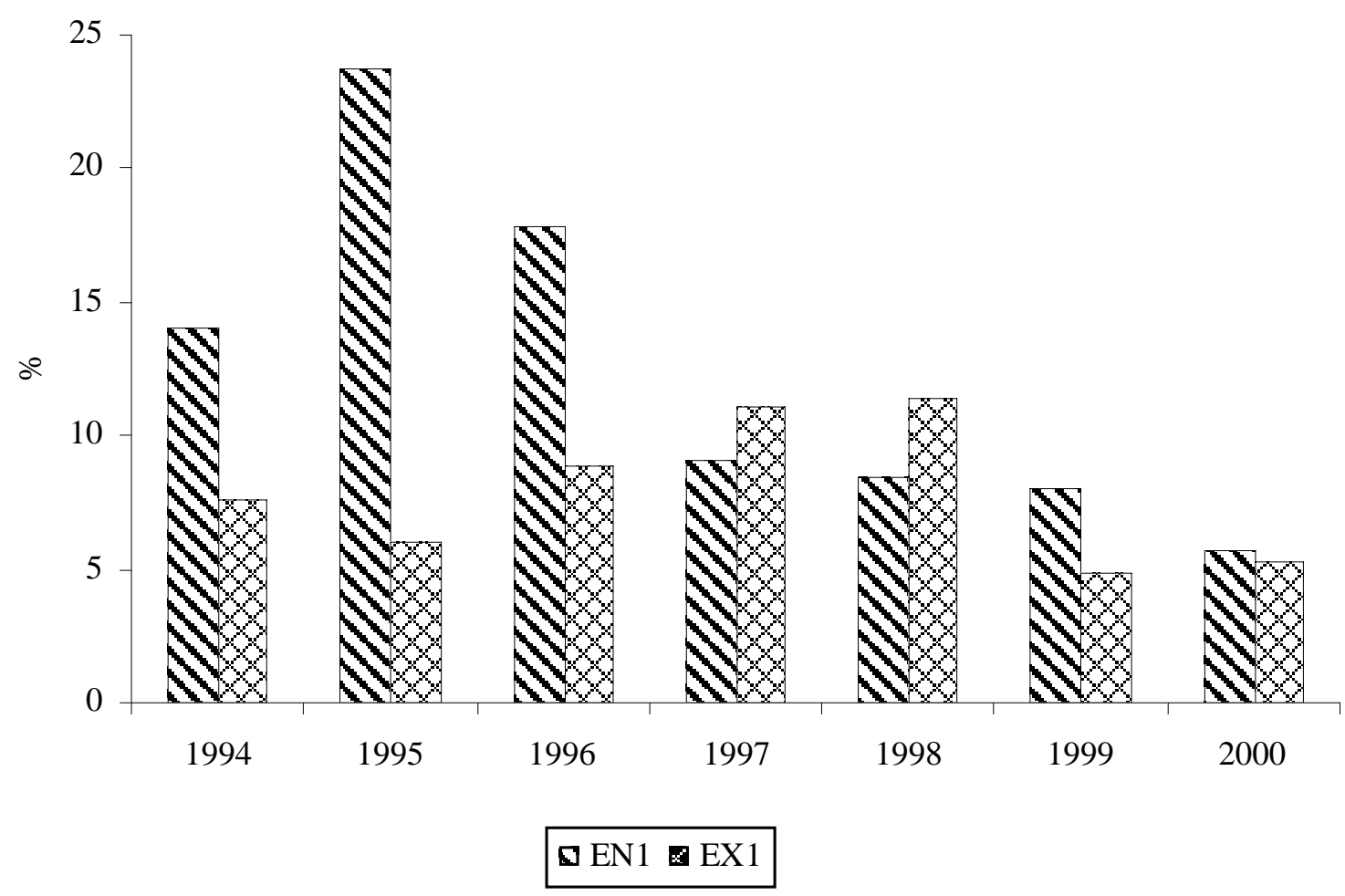

Figure 4 Entry and exit rates in Indonesian manufacturing in terms of employment (EN2 and EX2) (\%), 1994-2000 


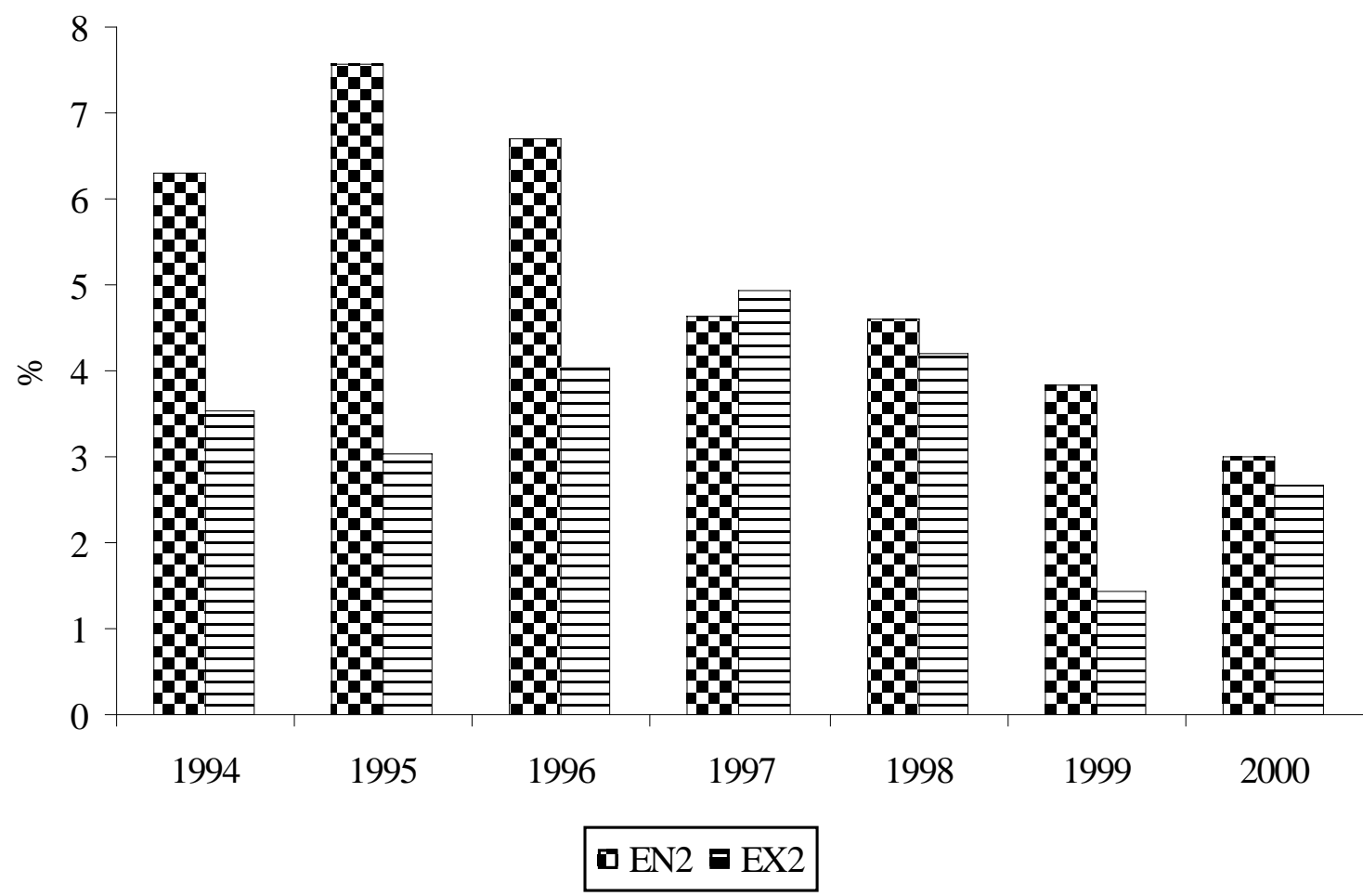

Turning to the impact on the closure of firms, Figure 3 shows that exit rates increased at the peak of the crisis. However, this negative impact seems to have disappeared by $1999-2000$. The exit rates returned to, and in fact were slightly below, that of the pre-crisis period. Unlike the entry rates, the trend in the exit rates is consistent with the general impression of fairly quick industrial recovery. In other words, most of the output recovery originated from firms that survived the crisis.

As defined, EN2 and EX2 measure the employment effects originating from the entering and exiting firms. The adjustment obviously does not only come from these firms, but also from incumbents. Computing employment change for incumbents indicates how the crisis affected their expansion and contraction. We define the rate of expansion (POS) in industry $j$ at time $t$ as

$P O S_{j, t}=\frac{E M P L_{-} P O S_{j, t}}{E M P L_{-} T_{j, t-1}}$

and the rate of contraction (NEG) in industry $j$ at time $t$ as

$$
N E G_{j, t}=\left|\frac{E M P L_{-} N E G_{j, t}}{E M P L_{-} T_{j, t-1}}\right|,
$$


where:

EMPL_POS $=$ employment of plants that expand between $t$ and $t-1$ EMPL_NEG $=$ employment of plants that contract between $t$ and $t-1$

A simple relationship that links EN2, EX2, POS and NEG is the following:

$$
E M P L_{-} G R O W T H_{j, t}=E N 2_{j, t}+P O S_{j, t}+E X 2_{j, t}+N E G_{j, t}
$$

where EMPL_GROWTH ${ }_{j, t}$ is the annual employment growth between $t$ and $t$ $1^{13}$ In other words, the relationship decomposes the annual employment change into the component associated with "growing-and-new" and "shrinking-and-exiting firms".

Figure 5 shows trends in the expansion and contraction rates for the period 1993-2000. The expansion rate declined significantly in 1997 and 1998 but recovered immediately in the following year. This is in contrast to the continuously declining trend in the entry rates observed earlier, but supports the inference that much of the industry's output recovery originated from firms that survived the crisis. The contraction rates shown in Figure 5 underline how dramatic was the adjustment of the incumbents. The rate in 1998 jumped to about double that of the pre-crisis period. Consistent with the recovery story, however, the rate started to decline in 1999 and by 2000 returned to that of the average pre-crisis period.

${ }^{13}$ The relationship and the definition of POS and NEG follow those devised in Davis et al. (1996). 
Figure 5 Expansion (POS) and contraction (NEG) rates (\%), 1994-2000

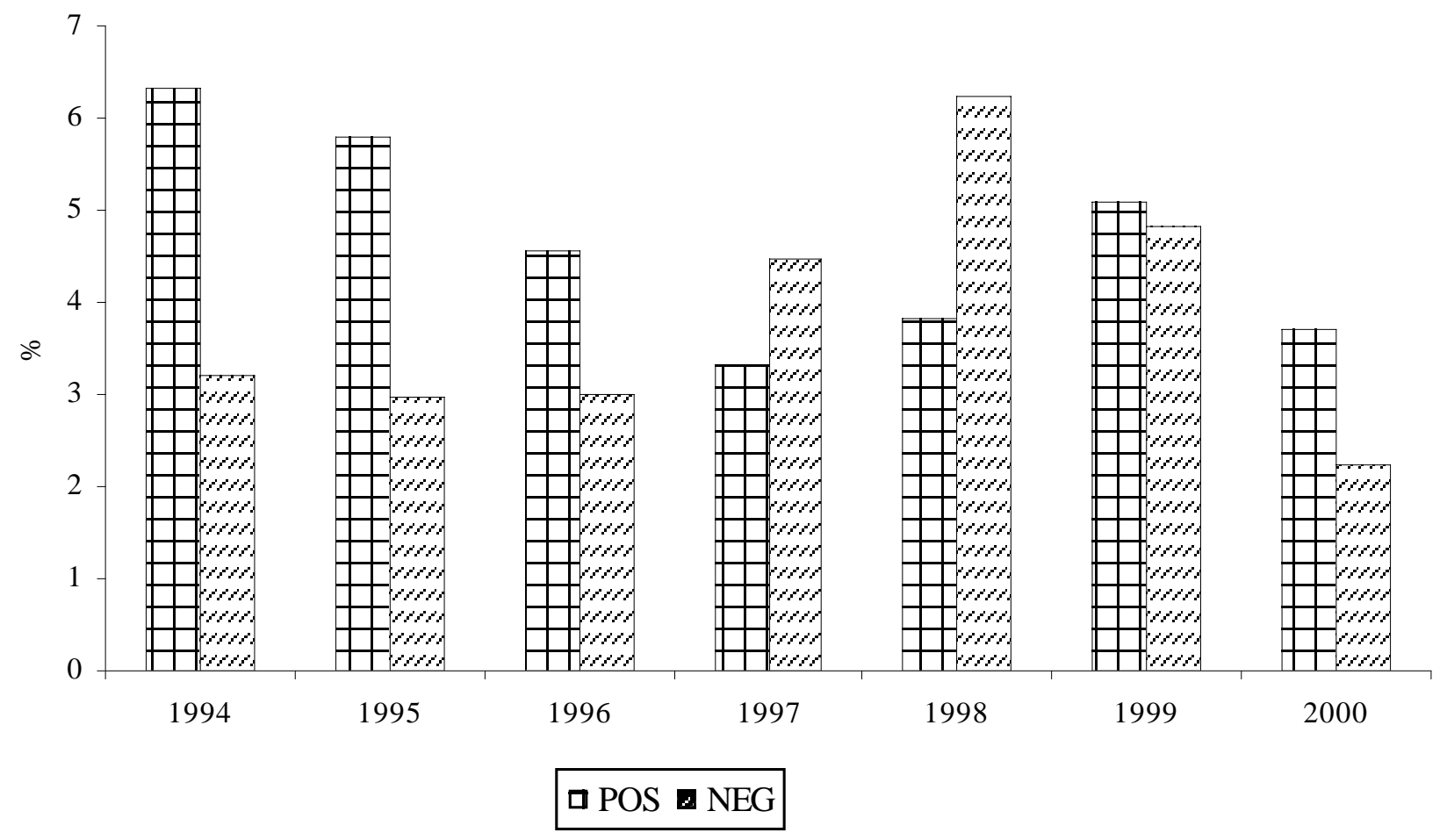

Figures $6 \mathrm{a}$ and $6 \mathrm{~b}$ decompose the annual employment change for the period 1994-2000, combining the estimates of EN2, POS, EX2 and NEG. The results show that the aggregate annual employment contraction in 1998 and 1999 was dominated by contraction from the incumbents, rather than from those which exited the industry (see Figure 6b). This indicates a high survival rate of firms, in the sense of weathering the crisis by reducing employment rather than declaring bankruptcy. It also contrasts with the pre-crisis pattern. As shown in Figure 6a, employment destruction in this period was almost evenly divided between that originating from incumbents and the exiting plants. 
Figure 6 Decomposition of employment growth (\%), 1994-2000

a. $1994-96$

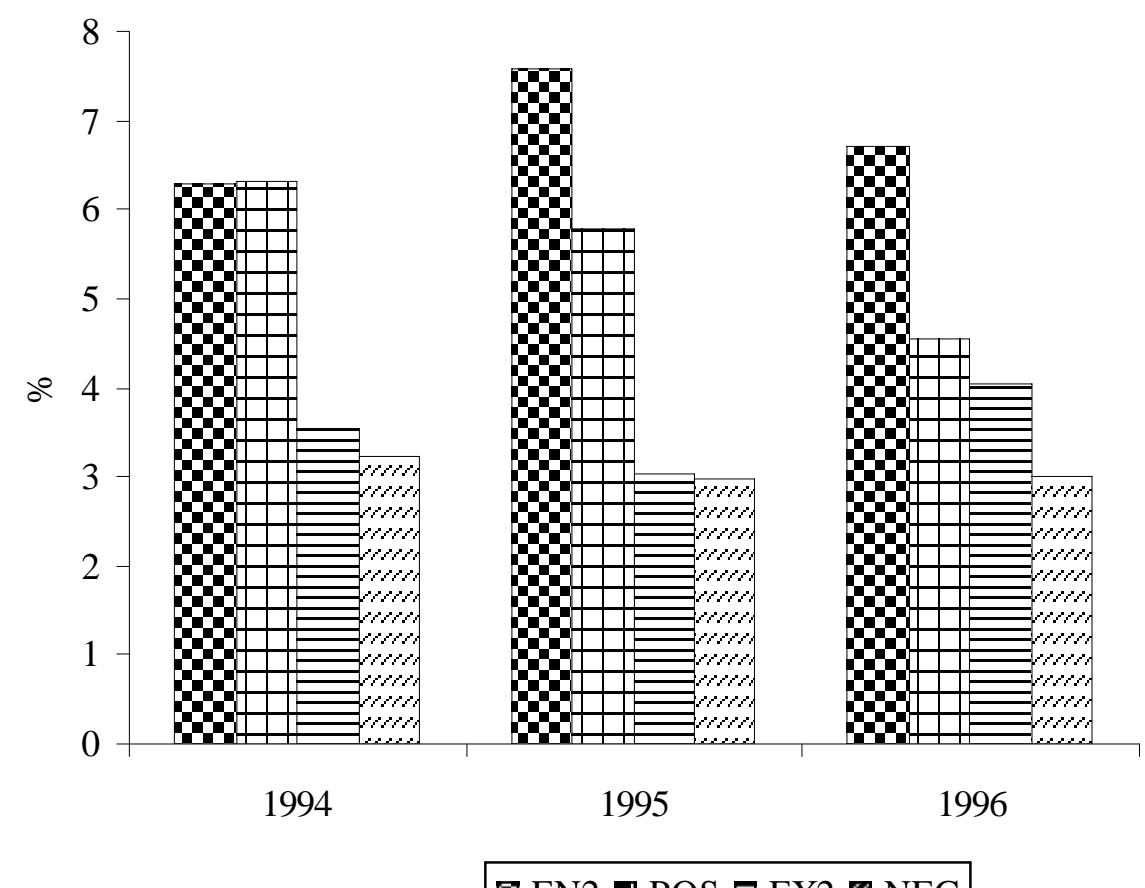

b. $1997-2000$

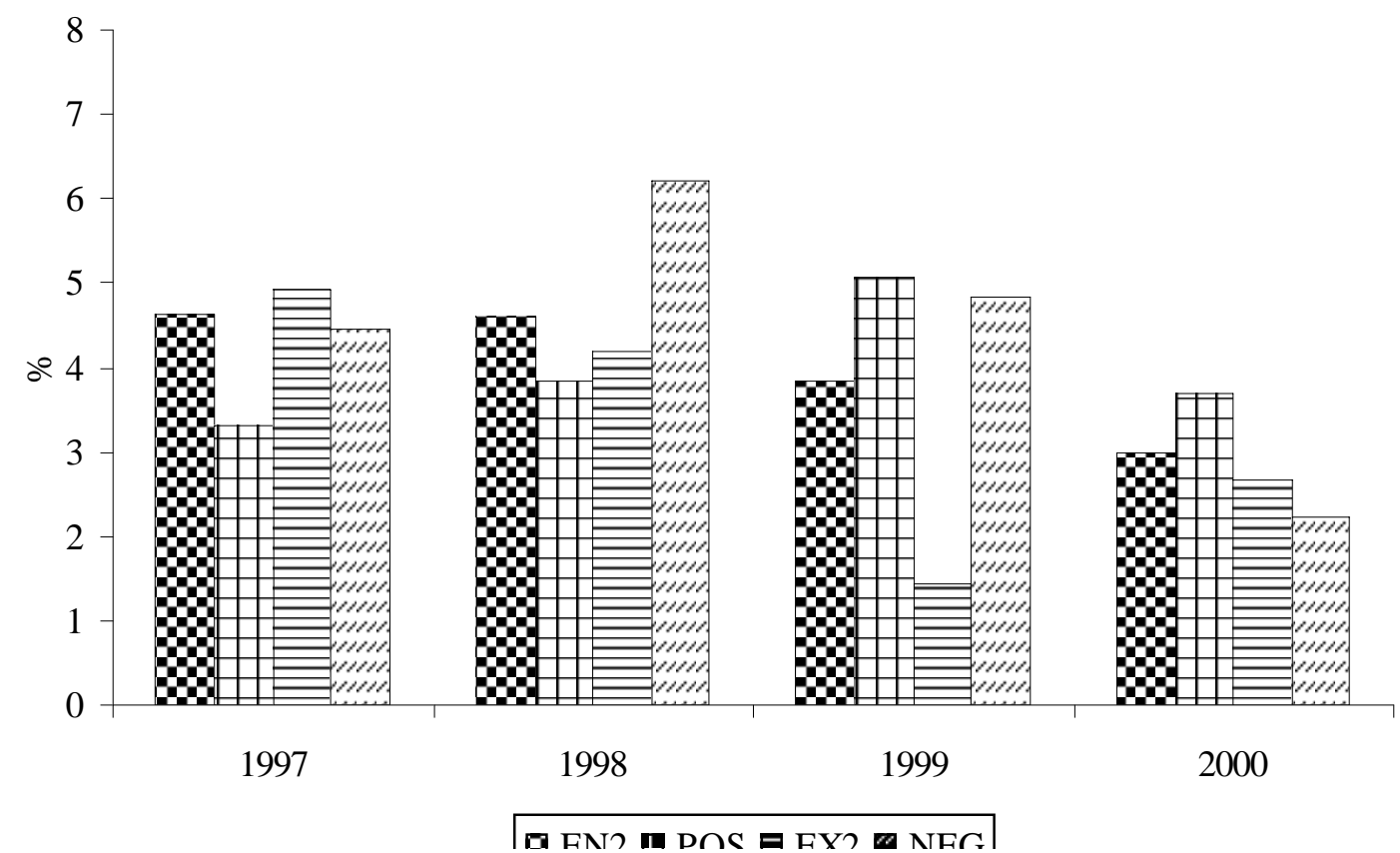

(4.2) The micro picture 
This section examines the impact of the crisis at the plant level. It addresses the question of whether the impact was distributed evenly across firms. Based on the discussion and literature in the previous section, we hypothesize that the impacts are uneven. We advance the following predictions for a range of firm and industry characteristics.

Sales orientation: Export-oriented firms are expected to have performed better than domestic-oriented ones. As argued above, it is expected that they were able to take advantage of the boost in competitiveness from the sharp exchange rate depreciation, even allowing for some of the factors adumbrated earlier which may have blunted these competitiveness impacts.

Ownership: We hypothesize a positive relationship between foreign ownership and firm performance, and that these firms will outperform the domesticprivate and state-owned enterprises. It might also be conjectured that the expected better performance of foreign firms would depend on the foreign equity share in these firms, though both the analytics and the literature provide less clear guidance on this issue. Similarly, for reasons advanced above, the relationship between SOE ownership and firm performance is likely to be ambiguous.

Size: As noted, the impact of firm size on performance during the crisis is difficult to predict a priori. Large firms might have been more successful because of advantages which stem from economies of scale, market power and employment of more skilled managers. Moreover, they are less likely to suffer from credit rationing as banks tended to adopt more stringent lending policies after the crisis. However, inflexibility to changes in the business environment and dependence on the financial sector might also have made them less successful than small firms. Small firms might also have performed better due to less expensive overheads and an ability to operate in niche markets which might not be so severely affected by the crisis.

Factor intensity: For reasons outlined above, firms in labour- and resourceintensive industries should have been less affected than those in capitalintensive industries.

To test these hypothesises, the mean of the percentage difference in $R V A$ at plant level $\left(\% \Delta R V A_{i, t}\right)$ is computed for every group of plants and the period 1998-2000. These results are presented in Table 3. $\% \Delta R V A_{i, t}$ is defined in a similar fashion as the difference at industry level,

$\% \Delta R V A_{i, t}=\frac{R V A_{i, t}-\overline{R V A}_{i, 9596}}{\overline{R V A}_{i, 9596}} \times 100$

where $i$ denotes plant $i$. The period $t$ covers the peak of the crisis (1998) and the early recovery period (1999-2000). Note that this definition unavoidably excludes 1997 owing to data ambiguities in that year. The 
variables related to firm characteristics are described in more detail in Appendix 2.

Table 3 The crisis performance impact by plant characteristics

\begin{tabular}{|c|c|c|c|}
\hline \multirow[t]{2}{*}{ Plant characteristic class } & \multicolumn{3}{|c|}{$\% \Delta R V A_{i, t}$} \\
\hline & 1998-2000 & 1998 & $1999-2000$ \\
\hline \multicolumn{4}{|l|}{ Sales orientation class } \\
\hline Domestic oriented & -19.6 & -22.2 & -12.1 \\
\hline Low export oriented & -19.9 & -22.1 & -13.6 \\
\hline Moderately export oriented & -3.0 & -4.2 & 1.4 \\
\hline Highly export oriented & 8.9 & 11.5 & 5.0 \\
\hline \multicolumn{4}{|l|}{ Ownership class } \\
\hline Foreign & 8.6 & 4.6 & 20.9 \\
\hline Private-domestic & -16.0 & -17.9 & -9.7 \\
\hline Government & -26.6 & -26.3 & -23.7 \\
\hline \multicolumn{4}{|l|}{ Foreign ownership class } \\
\hline Low & -42.5 & -45.4 & -19.1 \\
\hline Moderately low & -6.4 & -14.5 & 18.0 \\
\hline Moderately high & -4.8 & -7.8 & 3.2 \\
\hline High & 31.9 & 29.6 & 38.5 \\
\hline \multicolumn{4}{|l|}{ Size class } \\
\hline Small 1 & -15.4 & -17.4 & -8.5 \\
\hline Small 2 & -21.5 & -23.2 & -15.6 \\
\hline Medium 1 & -17.5 & -19.8 & -11.8 \\
\hline Medium 2 & -11.1 & -13.4 & -5.3 \\
\hline Large & 1.4 & 1.2 & 2.3 \\
\hline \multicolumn{4}{|l|}{ Industry factor intensity class } \\
\hline Resource-intensive & -18.9 & -14.9 & -16.2 \\
\hline Labour-intensive & -5.7 & -9.0 & 1.7 \\
\hline Capital-intensive & -25.0 & -31.7 & -12.8 \\
\hline
\end{tabular}

Source: Authors' computation.

Sales orientation: Plants are categorised into four groups based on their average export propensity in 1995 and $1996\left(E X P_{i, 9596}\right)$ : domestic oriented plants $\left(E X P_{i, 9596}\right.$ equal to zero); low export oriented plants $\left(E X P_{i, 9596}\right.$ between zero and 0.1); moderately export oriented ( $E X P_{i, 9596}$ between 0.1 and 0.5$)$ and 
highly export oriented $\left(E X P_{i, 9596}\right.$ greater than 0.5$)$. For the entire period, the table suggests a positive relationship, in that the contraction in $R V A$ decreases as export propensity increases. On average, the output of domestic and low export oriented plants contracted by about 20 per cent while moderately export oriented plants contracted by only 3 per cent. Plants with high export propensity benefited from the crisis, in the sense that their output expanded. The findings therefore support the hypothesis that export-oriented firms performed better than domestic-oriented ones.

Comparing the crisis peak and the early recovery periods, the positive impact of sales orientation seems to have been weaker during the early recovery. This is particularly clear for the group of plants with high export intensity, where the expansion was significantly lower in this period. This suggests that the one-off boost to competitiveness was relatively short-lived. An additional factor is that, while Indonesia's real effective exchange rate remained below the other crisis-affected economies, it was beginning to appreciate from the second half of 1998 owing to higher inflation (Athukorala, 2006).

Ownership: Plants are classified into groups with the three dummy ownership variables: domestic private $\left(D P R I_{i, 9596}\right)$, foreign $\left(D F O R_{i, 9596}\right)$, and government plants $\left(D S O E_{i, 9596}\right)$. The results support the hypothesis that foreign firms outperformed the two domestically-owned groups. The average output differences are positive during the peak of the crisis only for foreign firms. Moreover, the positive impact of foreign ownership is even higher in the early recovery period. By contrast, government firms were severely affected by the crisis. RVA on average fell by more than 20 per cent for the entire period 1998-2000. Evidently, the government was unable to support these firms, a factor attributable to its sharply deteriorating fiscal position, combined with the fact that most of the firm-level bail-outs occurred in the banking sector.

Within the foreign-owned firms, does the level of foreign ownership matter? To answer this question, these firms are classified into four groups: low foreign ownership (average foreign share in 1995 and 1996, or $F O R_{i, 9596}$ up to 20 per cent); moderately-low foreign ownership ( $F O R_{i, 9596}$ between 20 and 50 per cent); moderately-high foreign ownership $\left(F O R_{i, 9596}\right.$ between 50 and 80 per cent); and high foreign ownership ( $F O R_{i, 9596}$ greater than 80 per cent).

The results suggest that the level of foreign ownership matters. During the peak of the crisis, a positive relationship between contraction in performance and foreign ownership is indicated. That is, the contraction was lower among plants with higher foreign ownership. The output expansion observed earlier originated from those firms with high foreign ownership, as the expansion is large, about 30 per cent. By contrast, the average output contraction in firms with very low foreign ownership share was very large during the peak of the crisis, about 45 per cent. 
This positive relationship continues into the early recovery period, but the pattern is less pronounced. The high foreign ownership group again out performs the others, but firms with moderately-low foreign ownership performed better than those with moderately high foreign ownership. This is consistent with the frequently observed proposition that, cet par, MNEs are more willing to support their subsidiaries the more control they have over them.

Size: Firms are classified into five groups based on employment levels. These in turn may be broadly aggregated into small, medium and large firms. The small group includes those with employment in 1995 and 1996 (expressed as $S I Z E_{i, 9596}$ ) between 20-49 and 50-99), medium ( $\left.S I Z E_{i, 9596}\right)$ is employment in the ranges 100-199 and 200-499 employees, while large firms $\left(S I Z E_{i, 9596}\right)$ are those with more than 500 employees.

Both for the entire period 1998-2000 and the sub-periods, the results point to a positive relationship, in that the contraction is consistently lower for larger plants, with some large firms actually expanding their output. Among the small groups, the smallest firms (Small 1) contracted less than the next group (Small 2). Therefore, it is difficult to derive strong inferences from the results. One possible explanation for the mixed finding is that size might represent other plant characteristics that significantly affected performance. Large firms are often multinationals, exporters and located in concentrated industries. Therefore, these characteristics need to be controlled for to reveal the true relationship, an issue we address in the following sub-section.

Factor intensity: Firms are classified into three groups based on the dummyvariables representing industry factor intensity ( $D R I, D L I$ and $D C I)$. The results indicate that, as hypothesized, factor intensity was a significant determinant of performance. For the full period 1998-2000, a clear pattern is observed: firms in capital-intensive industries contracted the most severely while the opposite is the case for firms in labour-intensive industries. The pattern changes somewhat in the early recovery period. The average contraction for firms in capital-intensive industries was less for this period than during the peak of the crisis. This finding is consistent with the case study material cited earlier, which reported radical and prompt corporate change in response to the collapse in domestic demand at the peak of the crisis in industries such as chemicals and machinery. 


\section{(4.3) Econometric analysis}

The previous descriptive analysis revealed a number of relationships between firm characteristics and performance during the crisis. But these results are at best suggestive, of course, owing to the fact that firms typically share several characteristics. For example, foreign firms are often large and export oriented, and thus the positive effect of foreign ownership observed above could simply be due to some other characteristics. To ascertain whether these suggested relationships are robust, this section provides an integrated econometric analysis of the relationship between these characteristics and firm performance.

Specifically, we regress the percentage change in $R V A\left(\% \Delta R V A_{i, t}\right)$ on the firm characteristic variables over the period 1998-2000, controlling for differences across years, industries, regions and some additional variables not elsewhere considered in this paper. The estimating equation is as follows

$\% \Delta R V A_{i, t}=\alpha+\beta^{\prime} X_{i}+\delta^{\prime} Y_{j}+\varepsilon_{1 i, t}$

where $X_{i}$ and $Y_{j}$ are sets of explanatory variables capturing the firm characteristics at firm and industry level. The additional firm characteristic variables included in the equation are age, financial leverage, import dependence, industry concentration and import penetration, and trade protection. The dummy variables to represent region and industry are defined at the level of province and four-digit ISIC, respectively.

The sample is an unbalanced pooled cross-section which consists of 10,050 firms for the period 1996-2000. About 75 per cent of the sample is made up of firms which are observed for the entire period 1995-2000.

An important statistical issue regarding the estimation is sample censoring. The dependent variable $\left(\% \Delta R V A_{i, t}\right)$ can only be calculated for the plants observed throughout the period 1995-2000. An examination of the sample indicated that about 33 per cent of the observed plants were no longer recorded in one or more years during the period 1997-2000. As a result, the distribution of the sample is truncated and estimating equation 1 only on the selected sample may lead to bias. To solve this problem, the Heckman (1976) two-step estimation approach was employed. That is, the selection problem is solved by including an inverse Mills ratio as another explanatory variable in equation 1. This is done in two steps. First, a probit model of firm survival is regressed and the estimates of the inverse Mills ratio are constructed. Second, equation 1 is regressed with the estimated inverse Mills ratio as an additional regressor. ${ }^{14} \mathrm{~A}$ test for the selectivity problem can be undertaken by

\footnotetext{
${ }^{14}$ See, for example, Johnston and Dinardo (1997) for a fuller discussion of the Heckman method.
} 
evaluating the statistical significance of the estimated coefficient of the inverse Mills ratio.

In its general form, the survival equation is:

$S_{i, t}=1\left[\gamma^{\prime} Z_{i}+\varepsilon_{2 i, t}>0\right]$

where $S_{i, t}=1$ if plant $i$ is observed and zero otherwise, and $Z_{i}$ includes variables that determine the survival, that is, whether plant $i$ is observed or not.

We employ a similar analytical framework to explain firm survival during the crisis as was used to understand the impact of the crisis. Hence the same set of explanatory variables is included in both equations 1 and 2. Although financial distress is likely to be a key determinant of survival, Geroski and Gregg (1997) and Schary (1991) have pointed out that the decision to put a firm into receivership may be constrained by firm characteristics. These include size (see Jovanovic 1982; Ghemawat and Nalebuff 1985), age (Jovanovic 1982) and financial leverage (Jones 1987; Schary 1991).

The regression results from equation 1 are reported in Table 4. These are ordinary least square (OLS) estimations from the second stage of the Heckman selection model. The F-test for overall statistical significance passes at the 1 per cent level. The White's robust F- and t-statistics were used to correct for heteroscedasticity. Graphical examination and heteroscedasticity tests (Cook-Weisberg and White) at the experimental stage reveal that the variance is not homogenous. SIZE $E_{9596}$ was introduced in its natural logarithm form, following previous studies which found that firm size is non-linearly related to performance.

We experimented with five specifications. Specifications 1 and 2 are the results for the entire period 1998-2000 while specifications 3 to 5 are the results of separate regressions for each year within the period. The last three specifications are motivated by the possibility that the effect of the characteristics might have changed as the economy began to recover in 1999. 
Table 4 The determinants of performance impact of the crisis: regression results

\begin{tabular}{|c|c|c|c|c|c|}
\hline \multirow{3}{*}{$\begin{array}{l}\text { Dependent variable } \\
\text { Period or year } \\
\text { Specification }\end{array}$} & \multicolumn{5}{|c|}{$\% \Delta R V A_{i, t}$} \\
\hline & \multicolumn{2}{|c|}{ Entire period $1998-2000$} & 1998 & 1999 & 2000 \\
\hline & 1 & 2 & 3 & 4 & 5 \\
\hline $\mathrm{EXP}_{\mathrm{i}, 9596}$ & $\begin{array}{c}0.181 \\
(6.04)^{* *}\end{array}$ & $\begin{array}{c}0.174 \\
(5.79)^{\star *}\end{array}$ & $\begin{array}{c}0.285 \\
(4.65)^{\star *}\end{array}$ & $\begin{array}{c}0.195 \\
(3.09)^{* *}\end{array}$ & $\begin{array}{c}0.148 \\
(2.20)^{*}\end{array}$ \\
\hline $\mathrm{FOR}_{\mathrm{i}, 9596}$ & $\begin{array}{c}0.230 \\
(5.62)^{\star \star}\end{array}$ & & $\begin{array}{c}0.217 \\
(2.38)^{*}\end{array}$ & $\begin{array}{c}0.291 \\
(3.55)^{\star \star}\end{array}$ & $\begin{array}{c}0.392 \\
(4.75)^{\star \star}\end{array}$ \\
\hline DFOR $_{\mathrm{i}, 9596}$ & & $\begin{array}{l}-0.304 \\
(3.56)^{\star *}\end{array}$ & & & \\
\hline DFOR $_{i, 9596}{ }^{*} \mathrm{FOR}_{\mathrm{i}, 9596}$ & & $\begin{array}{c}0.620 \\
(5.26)^{\star *}\end{array}$ & & & \\
\hline DGOV $_{i, 9596}$ & & $\begin{array}{l}0.050 \\
(1.51)\end{array}$ & & & \\
\hline $\log \left(\mathrm{SIZE}_{\mathrm{i}, 9596}\right)$ & $\begin{array}{c}-0.022 \\
(1.71)+\end{array}$ & $\begin{array}{l}-0.020 \\
(1.60)\end{array}$ & $\begin{array}{l}-0.030 \\
(1.02)\end{array}$ & $\begin{array}{c}0.046 \\
(1.70)+\end{array}$ & $\begin{array}{l}0.038 \\
(1.22)\end{array}$ \\
\hline $\mathrm{DLI}_{\mathrm{j}, 9596}$ & $\begin{array}{l}0.045 \\
(0.86)\end{array}$ & $\begin{array}{l}0.047 \\
(0.92)\end{array}$ & $\begin{array}{c}0.228 \\
(2.04)^{*}\end{array}$ & $\begin{array}{l}0.097 \\
(0.99)\end{array}$ & $\begin{array}{c}-0.068 \\
(0.60)\end{array}$ \\
\hline $\mathrm{DCl}_{\mathrm{j}, 9596}$ & $\begin{array}{l}-0.192 \\
(1.42)\end{array}$ & $\begin{array}{l}-0.206 \\
(1.51)\end{array}$ & $\begin{array}{l}-0.012 \\
(0.06)\end{array}$ & $\begin{array}{l}-0.450 \\
(2.25)^{\star}\end{array}$ & $\begin{array}{l}-0.401 \\
(1.02)\end{array}$ \\
\hline $\begin{array}{l}\text { R-squared } \\
\text { F-statistics }\end{array}$ & $\begin{array}{c}0.05 \\
14.34\end{array}$ & $\begin{array}{c}0.05 \\
14.28\end{array}$ & $\begin{array}{l}0.06 \\
4.79\end{array}$ & $\begin{array}{l}0.08 \\
5.92\end{array}$ & $\begin{array}{l}0.07 \\
4.95\end{array}$ \\
\hline r-staustICS & & & & & \\
\hline
\end{tabular}

Notes:

1) The results of the other variables are suppressed.

2) Robust t statistics in parentheses.

3) Significance level: ${ }^{* *}$ significant at $1 \%$; ${ }^{*}$ significant at $5 \%$; + significant at $10 \%$

The results based on specifications 1 and 2 show a robust finding that export oriented firms performed better than domestic oriented ones. The coefficients of $E X P_{9596}$ are positive and statistically significant across the equations. The effect of sales orientation is sizeable. A 10 per cent increase in exported output (as a ratio to total output) lowers the contraction in RVA by 10 per cent. The finding is consistent with expectations from theory regarding the positive impact of exchange rate depreciation, and it supports findings from other studies (e.g. Forbes 2000b; Bappenas 2000; Blalock and Gertler 2005). Nevertheless, and as noted above, the positive impact of sales orientation begins to 'wash out' fairly quickly, as shown by the difference between the peak of the crisis and the early recovery period. 
There is strong evidence on the positive effect of foreign ownership, confirming the finding from the descriptive analysis that firms with a higher foreign share perform more strongly during the crisis. The coefficients of $F O R_{9596}$ are positive and statistically significant. In addition, the magnitude of the coefficients suggests the effect of foreign ownership is economically important. A 10 per cent increase in foreign share leads to a smaller RVA contraction by 12 per cent.

Specification 2 replaces the continuous ownership-variables $\left(F O R_{9596}, G O V_{9596}\right)$ with the dummy ownership-variables $\left(D P R I_{i}, D_{F O R_{i}}\right.$ and $\left.D S O E_{i}\right)$ and adds an interaction variable between the dummy for foreign plants and the share of foreign ownership $\left(D F O R_{i, 9596} * F O R_{i, 9596}\right)$. The substitution and addition aim to test for whether the level of foreign ownership matters. The results do indeed support the hypothesis. The coefficient of the interactive variable is positive and statistically highly significant. This finding thus supports the proposition that parent companies are more likely to support their affiliates when they have a greater equity stake in them.

The parameter estimates of the second specification are used to estimate the minimum foreign share required to have at least zero percentage difference in performance (i.e. $\% \Delta y_{i, t}=0$ ). It turns out that the estimate is quite high, around 40 per cent. Based on this estimate, it can be concluded that foreign firms in general did not necessarily perform better than the others. Rather, it was only those with a high foreign ownership share that exhibited superior performance.

Contrary to the results from the descriptive analysis, the regression results suggest that large firms contracted more than smaller firms. The coefficient of $\log \left(S I Z E_{9596}\right)$ is negative in specifications 1 and 2 . This inference, however, is not very strong, since the coefficient is statistically significant only at the 10 per cent level in specification 1 and is not statistically significant in specification 2 .

The results support the observations from the descriptive analysis regarding the importance of factor intensity, based on the coefficients of $D L I_{9596}$ and $D C I_{9596}$. After controlling for other plant characteristics, on average, firms in capital intensive industries contracted more than those in resource-intensive industries. This is shown by the negative coefficients of $D C I_{9596}$ in all equations, even though only a few are statistically significant. ( $D R I_{9596}$ here is used as the base dummy variable.) The positive coefficients of $D L I_{9596}$ in the equations suggest firms in labour-intensive industries performed better than those in resource-intensive industries. Nevertheless, none of the results is statistically significant, which suggests that performance in these two industries is quite similar. 
The results of specification 3 to 5 reveal several interesting findings. First, there is some evidence of a positive and substantial effect for firm size in the early recovery period. The coefficients of $\log \left(S I Z E_{9596}\right)$ are positive and larger in the results for 1999 and 2000 compared with those for 1998. Despite this, the coefficients are only significant at the 10 per cent level for 1999 .

This finding differs somewhat from some previous studies (e.g. Forbes 2000b; Berry et al. 2001) which conclude that smaller firms perform better than larger ones during the crisis. For example, using firm-level data from the Indonesian Ministry of Cooperatives and SMEs (MOCSME), Berry et al. found that small firms expanded their value added by about 35 per cent in 1998 compared to a contraction of 5 to 27 per cent experienced by large firms. ${ }^{15}$ Nevertheless, the finding is in line with previous studies which examined the relationship using other performance measures and a different data source. Using The World Bank firm level survey, Dwor-Frecaut et al. (2000) found the firms that expanded exports in Thailand and Malaysia during the period 1998-99 were mostly large (about 60 per cent of firms in the sample). Moreover, Claessens et al. (2000) found that the 1998 sales margin of some publicly listed companies in six East Asian economies (the four crisis-affected together with Singapore and Hong Kong) is positively related to firm size, the latter proxied by the log of firms' sales in 1996.

The second key finding is that the positive effect of foreign ownership became more important in the recovery period. The coefficients of $F O R_{9596}$ increase and become more statistically significant over the period. This finding presumably reflects the effects of an intensifying competitive environment. It is also generally found in the literature. Foreign firms have both the deeper pockets necessary to endure a domestic demand collapse, and greater opportunities for export expansion. They are also more likely to be able to capitalize on structural reforms triggered by the economic recovery program. ${ }^{16}$

A third finding is that the effect of sales orientation is less important in the early recovery period. Both the coefficients of $E X P_{9596}$ and their statistical significance decrease over time. This suggests that the export response to the crisis was significantly lower over the recovery period, for reasons discussed above.

Table 5 reports the probit regression results relating to the determinants of survival during the period 1997-2000. They correspond to the OLS regression

\footnotetext{
${ }^{15}$ However, it is important to bear in mind that the data used in our study (i.e. the SI data) are different to those of MOCSME in three respects. First, the SI data do not include plants with less than 20 employees. Second, MOCSME data define size in terms of output rather than employment. Third, MOCSME data include all types of commercial activities, not only manufacturing. ${ }^{16}$ See, for example, Soesastro and Basri (1998), who describe the early trade and investment reforms originating from the IMF recovery programs.
} 
results presented in Table 4. The probit regressions are the first step in the Heckman selection model.

Table 5 The determinants of survival: regression results

\begin{tabular}{|c|c|c|c|c|c|}
\hline \multirow{3}{*}{$\begin{array}{l}\text { Dependent variable } \\
\text { Period or year } \\
\text { Specification }\end{array}$} & \multicolumn{5}{|c|}{$S_{i+}$} \\
\hline & \multicolumn{2}{|c|}{ Entire period 1998-2000 } & 1998 & 1999 & 2000 \\
\hline & 6 & 7 & 8 & 9 & 10 \\
\hline \multirow[t]{2}{*}{$\mathrm{EXP}_{\mathrm{i}, 9596}$} & 0.017 & 0.015 & 0.024 & 0.015 & 0.008 \\
\hline & (1.59) & (1.59) & $(0.77)$ & (1.08) & $(0.86)$ \\
\hline \multirow[t]{2}{*}{$\mathrm{FOR}_{\mathrm{i}, 9596}$} & 0.091 & & 0.096 & 0.091 & 0.049 \\
\hline & $(1.74)+$ & & $(1.87)+$ & $(1.71)+$ & $(0.51)$ \\
\hline DFOR $_{i, 9596}$ & & $\begin{array}{c}-0.075 \\
(0.69)\end{array}$ & & & \\
\hline $\mathrm{DFOR}_{\mathrm{i}, 9596}{ }^{*} \mathrm{FOR}_{\mathrm{i}, 9596}$ & & $\begin{array}{c}0.187 \\
(1.88)+\end{array}$ & & & \\
\hline $\mathrm{DGOV}_{\mathrm{i}, 9596}$ & & $\begin{array}{l}0.015 \\
(0.24)\end{array}$ & & & \\
\hline \multirow[t]{2}{*}{$\log \left(\right.$ SIZE $\left._{i, 9596}\right)$} & 0.403 & 0.404 & 0.418 & 0.444 & 0.412 \\
\hline & $(35.66)^{\star \star}$ & $(35.48)^{\star \star}$ & $(18.21)^{\star *}$ & $(19.95)^{\star *}$ & $(19.86)^{\star \star}$ \\
\hline \multirow[t]{2}{*}{$\mathrm{DLI}_{\mathrm{j}, 9596}$} & 0.265 & 0.265 & 0.328 & 0.269 & 0.237 \\
\hline & $(3.05)^{\star \star}$ & $(3.05)^{\star \star}$ & $(1.81)+$ & (1.63) & (1.49) \\
\hline \multirow[t]{2}{*}{$\mathrm{DCl}_{\mathrm{j}, 9596}$} & -0.111 & -0.112 & -0.085 & -0.165 & -0.222 \\
\hline & $(0.56)$ & $(0.57)$ & $(0.21)$ & $(0.42)$ & $(0.59)$ \\
\hline Pseudo R-squared & 0.15 & 0.15 & 0.15 & 0.15 & 0.14 \\
\hline Wald $\mathrm{Chi}^{2}$ & 3774.41 & 3767.73 & 955.11 & 1026.24 & 1068.09 \\
\hline
\end{tabular}

Notes:

1) The results of the other variables are suppressed.

2) Robust $Z$ statistics in parentheses.

3) Significance level: ${ }^{* *}$ significant at 1\%; * significant at 5\%; + significant at $10 \%$

The results of specifications 6 and 7 for the entire period 1998-2000 show that size is important in increasing plant survival probability during the period. The coefficients of $\log \left(S I Z E_{9596}\right)$ are positive, large and statistically very significant in all specifications. This finding is consistent with much of the literature on the determinants of firm survival, which draws attention to financial market access and economies of scale. This was a period when many Indonesian firms were experiencing serious financial difficulties. The results support anecdotal observations at the time that banks were willing to bear the risks in allowing large firms to keep operating. This too is consistent with the credit rationing literature, and with the fact that banks are likely to have better information on 
the financial conditions and investment opportunities of larger firms (Petersen and Rajan 1994).

The results indicate that the probability of survival is higher for foreign and export-oriented firms. The coefficients of variables that represent foreign ownership $\left(F O R_{9596}\right.$ and $\left.D^{2} O_{9596}\right)$ are positive, albeit only statistically significant at 10 per cent level. This finding is consistent with the results reported above concerning both foreign ownership variables.

However, unlike the finding on foreign ownership, the positive coefficients of $E X P_{9596}$ are statistically significant only at the 12 per cent level. Thus, export oriented plants were not more likely to survive than domestic-oriented ones. This finding most likely reflects the effect of many factors contributing to sluggish export performance during the crisis, as noted above and highlighted in a number of studies. ${ }^{17}$

Factor intensity is also an important determinant of firm survival. The coefficient of $D L I_{9596}$ is positive and statistically significant, indicating that firms in labour-intensive industries survived better than those in resourceintensive industries. This finding is consistent with the results of the performance equation above. The higher survival probability presumably reflects the success of these firms in managing financial distress through intensified export orientation. The positive coefficient also suggests the likelihood of labour hoarding during the crisis, as found in a number of studies (e.g. Dwor-Frecaut et al. 2000; Manning 2000).

The results of the last three specifications do not change this general picture. There is no change in terms of the determinants of survival, or the direction of the effects over time. Nevertheless, two additional findings deserve comment. First, the results on $F_{0 R}$ s suggest that the positive effects of foreign ownership were the greatest at the peak of the crisis. This differs from the finding in the performance equations, but it does provide evidence to support the hypothesis that foreign firms tend to support struggling affiliates. It is consistent, for example, with the observation made by Fukao (2001) that Japanese parent companies financially assisted their crisis-affected affiliates and enabled them to switch from local to export sales.

Second, the positive effect of sales orientation on survival is lower in the early recovery period, as indicated by the declining coefficients of $\operatorname{EXP}_{9596}$ over time. This again supports the observation that the initially strong export response to the crisis tapered off as the recovery proceeded.

\footnotetext{
${ }^{17}$ See for example Duttagupta and Spilimbergo 2004; ADB 2002; World Bank 2000; Hill 2000.
} 


\section{(5) Conclusions and Implications}

This paper has examined firm-level impacts of Indonesia's deep economic crisis of 1997-98 with the aid of detailed, establishment-level data. These impacts were highly variable, and many of the outcomes can be explained with reference to the crises literature. In particular, foreign ownership and prior export orientation were generally found to be highly significant determinants of survival and recovery. Firm size was found to be ambiguous, a result which tends to refute the popular notion that smaller firms are more adaptable in times of crisis. The industry in which firms are located, in particular its factor proportions, is also found to be significant.

Even though the data base is rich by developing country standards, inevitably there are some limitations. Very small firms, employing less than 20 workers, are not included in the survey. We also lack detailed information on financial arrangements and, for multi-plant operations, the nature of inter-affiliate transactions.

This paper is concerned not with the causes of the crisis but its consequences. It is important in this context to underline the importance of openness and global integration as key factors in the recovery. That is, firms which are foreign-owned, export-oriented, and particularly both, are clearly more likely to recover quickly, for reasons discussed in the paper. The origins of the Indonesian crisis were at least partly external, that is, the capital flight in the second half of 1997, compounded by misdiagnosis on the part of international financial institutions (Stiglitz, 2002). However, our analysis strongly indicates that these cautionary tales on the impact of globalization in no way weaken the case for open trade and FDI policies. When properly managed, they contribute to rapid growth, and are central to post-crisis recovery trajectories. 


\section{References}

ADB (2002), 'Did East-Asian Developing Economies Lose Export Competitiveness in the Pre-Crisis 1990s?', ADB Institute Research Paper, No. 34, Tokyo: ADB Institute.

Ariff, M. and H. Hill (1985), Export-Oriented Industrialisation: The ASEAN Experience. Sydney: Allen and Unwin.

Aswicahyono, H.H. and H. Hill (1995), 'Determinants of Foreign Ownership in LDC Manufacturing: An Indonesian Case Study', Journal of International Business Studies, 26 (1), pp.139-158.

Aswicahyono, H.H., M.C. Basri, and H. Hill (2000), 'How Not to Industrialise? Indonesia's Automotive Industry', Bulletin of Indonesian Economic Studies, 36 (1), pp. 209-241.

Athukorala, P.-C. (2003), 'Foreign Direct Investment in Crisis and Recovery: Lessons from the 1997-1998 Asian Crisis', Australian Economic History Review, 43 92), pp. 197-213.

Athukorala. P.-C. (2006), 'Post-crisis Export Performance: the Indonesian Experience in Regional Perspective', Bulletin of Indonesian Economic Studies, 42 (2), pp. 177-211.

Berry, A., E. Rodriguez and H. Sandee (2001), 'Small and Medium Enterprise Dynamics In Indonesia', Bulletin of Indonesian Economic Studies, 37(3), pp. 363-84.

Blalock, G. and P.J. Gertler (2005), 'Foreign Direct Investment and Externalities: The Case for Public Intervention', in T.H. Moran, E.M. Graham and M. Blomstrom (eds), Does Foreign Direct Investment Promote Development?, Washington DC: Institute for International Economics, pp. 73106.

Claessens, S., S. Djankov and L.C. Xu (2000), 'Corporate Performance in the East Asian Financial Crisis', World Bank Research Observer, 15(1), pp.23-46.

Davis, S.L., J.C. Haltiwanger and S. Schuh (1996), Job Creation and Destruction. Cambridge, MA: MIT Press.

Desai, M., C.F. Foley and K.J. Forbes (2004), 'Financial Constraints and Growth: Multinational and Local Firm Responses to Currency Crises', NBER Working Paper Series, No. 10545, Cambridge, MA: NBER.

Domowitz, I., R.G. Hubbard and B.C. Petersen (1986), 'Business Cycles and the Relationship between Concentration and Price-cost Margins', RAND Journal of Economics, 14(1), pp. 1-17. 
Duttagupta, R. and A. Spilimbergo (2004), 'What Happened to Asian Exports during the Crisis?', IMF Staff Papers, 51(1), pp.72-95.

Dwor-Frecaut, D., F. Colaco and M. Hallward-Driemeier (eds.) (2000), Asian Corporate Recovery: Findings from Firm-level Surveys in Five Countries, Washington DC: The World Bank.

Feridhanusetyawan, T., H. Aswicahyono and T. Anas, 'The Economic Crisis and the Manufacturing Industry: the Role of Industrial Networks, CSIS Economics Working Paper Series, No. 53, Jakarta: CSIS.

Forbes, K.J. (2000a), 'Cheap Labor Meets Costly Capital: the Impact of Devaluations on Commodity Firms', Journal of Development Economics, 69(1), pp.335-65.

Forbes, K.J. (2002b). "How do Large Depreciations Affect Firm Performance?, IMF Staff Papers, 49, pp. 214-238.

Fukao, K. (2001), 'How Japanese Subsidiaries in Asia Responded to Regional Crisis: an Empirical Analysis based on the MITI Survey', in T. Ito and A.O. Krueger (eds.), Regional and Global Capital Flows: Macroeconomic Causes and Consequences, Chicago: The University of Chicago Press, pp.267-303.

Fukuchi, T. (2000), 'Econometric Analysis of the Effects of Krismon Shocks on Indonesia's Industrial Subsector', Developing Economies, 38(4), pp.490-517.

Geroski, P.A. and P. Gregg (1997), Coping with Recession: UK Company Performance in Adversity. London: Cambridge University Press.

Ghemawat, P. and B. Nalebuff (1985), 'Exit', RAND Journal of Economics, 16(2), pp. 184-94.

Glick, R., R. Moreno and M.M. Spiegel (eds) (2001), Financial Crises in Emerging Markets, Cambridge: Cambridge University Press.

Gupta, P., D. Mishra and R. Sahay (2003), 'Output Response to Currency Crisis', IMF Working Paper, No. 230, Washington, DC: IMF.

Highfield, R. and R. Smiley (1987), 'New Business Starts and Economic Activity: an Empirical Investigation, International Journal of Industrial Organization, 5(1), pp.51-56.

Hill, H. (1997), Indonesia's Industrial Transformation, Singapore: ISEAS.

Hill, H. (2000), The Indonesian Economy, Cambridge: Cambridge University Press, second edition. 
Jones, F.L. (1987), 'Current Techniques in Bankruptcy Prediction', Journal of Accounting Literature, 6, pp. 131-64.

Johnston, J. and J. Dinardo (1997), Econometric Methods. Singapore: McGraw-Hill.

Jovanovic, B. (1982), "Selection and the Evolution of Industry", Econometrica, 50 (3), pp.649-70.

Kawai, M. et al (2000), 'Corporate Foreign Debt in East Asia: Too Much or Too Little?', in Dwor-Frecaut et al (eds), pp. 111-121.

Krueger, A.O. and A. Tornell (1999), 'The Role of Bank Restructuring in Recovering from Crisis: Mexico 1995-98', NBER Working Paper, no. 7042, Cambridge, Mass.

Krugman, P. (ed) (2001), Currency Crises, Chicago: University of Chicago Press.

Lipsey, R.E. (2001), 'Foreign Investment in Three Financial Crises', NBER Working Paper, no. 8084, Cambridge, Mass.

Manning, C. (2000), 'Labour Market Adjustment to Indonesia's Economic Crisis: Context, Trends and Implications, Bulletin of Indonesian Economic Studies, 36(1), pp.105-36.

Narjoko, D.A. (2006), 'Indonesian Manufacturing and the Economic Crisis of 1997/98', unpublished PhD thesis, Australian National University, Canberra.

Nickell, S. (1995), The Performance of Companies. Oxford: Basil Blackwell.

Petersen, M.A. And R.G. Rajan (1994), "The Benefits of Firm-creditor Relationship: Evidence from Small Business Data, Journal of Finance, 49(1), pp.3-37.

Ramstetter, E.D. (1999), 'Trade Propensities and Foreign Ownership Shares in Indonesian Manufacturing', Bulletin of Indonesian Economic Studies, 36(2), pp.61-95.

Ramstetter, E.D. and F. Sjoholm (eds) (2006), Multinational Corporations in Indonesia and Thailand: Wages, Productivity and Exports, London: Palgrave Macmillan.

Rosner, L.P. (2000), 'Indonesia's Non-oil Export Performance during the Economic Crisis: Distinguishing Price Trends from Quantity Trends,' Bulletin of Indonesian Economic Studies, 36(2), pp.61-95. 
Rotemberg, J.J. and G. Saloner (1986), 'A Supergame-theoritic Model of Price Wars during Booms', American Economic Review, 76(3), pp.390-407.

Schary, M.A. (1991), 'Probability of Exit', RAND Journal of Economics, 22(3), pp. 339-53.

Soesastro, H. and M.C. Basri (1998), 'Survey of Recent Developments', Bulletin of Indonesian Economic Studies, 34(1), pp.3-54.

Stiglitz, J. (2002), Globalization and its Discontents, London: Allen Lane The Penguin Press.

Temple, J. (2003), 'Growing into Trouble: Indonesia after 1966', in D. Rodrik (ed), In Search of Prosperity: Analytical Narratives on Economic Growth, Princeton: Princeton University Press.

Thee, K.W. (2000), 'The Impact of the Economic Crisis on Indonesia's Manufacturing Sector, Developing Economies, 38(4), pp.420-53.

Urata, S. (2002) 'Japanese Foreign Direct Investment in East Asia with Particular Focus on ASEAN4', paper prepared for a conference on 'Foreign Direct Investment: Opportunities and Challenges for Cambodia, Laos and Vietnam', Hanoi, August 16-17.

World Bank (2000), East Asia: Recovery and Beyond. Washington D.C.: World Bank

Yamawaki, H. (1991), 'The Effects of Business Condition on Net Entry: Evidence from Japan', in P. Geroski and J. Schwalbach (eds.), Entry and Market Contestability: An International Comparison. Oxford: Basil Blackwell, pp.168-85. 


\section{Data Appendices}

\section{(1) Definition of entry and exit rates}

$E N 1$ and $E X 1$ for industry $j$ between $t$ and $t-1$ are defined as

$$
\begin{aligned}
& E N 1_{j, t}=\frac{N E P_{j, t}}{N T P_{j, t-1}}, \\
& E X 1_{j, t}=\frac{N X P_{j, t}}{N T P_{j, t-1}},
\end{aligned}
$$

where: $\quad N E P_{j, t}=$ number of plants that enter industry $j$ between $t$ and $t-1$

$N X P_{j, t}=$ number of plants that exit industry $j$ between $t$ and $t-1$

$$
N T P_{j, t-1}=\text { number of plants in industry } j \text { in year } t-1
$$

EN2 and EX2 for industry $j$ between $t$ and $t-1$ are defined as

$$
\begin{aligned}
& E N 2_{j, t}=\frac{E M P L_{-} E N_{j, t}}{E M P L_{-} T_{j, t-1}}, \\
& E X 2_{j, t}=\frac{E M P L_{-} E X_{j, t}}{E M P L_{-} T_{j, t-1}},
\end{aligned}
$$

where: $\quad E M P L_{-} E N_{j, t}=$ employment in plants that enter industry $j$ between

$$
t \text { and } t-1
$$

$E M P L_{-} E X_{j, t}=$ employment in plants that exit industry between

$$
t \text { and } t-1
$$

$E M P L_{-} T_{j, t-1}=$ employment in plants in industry $j$ in $t-1$

\section{(2) Definition of variables}

The following variables are employed to describe firm characteristics. Unless otherwise stated, the variables are defined by their pre-crisis values, i.e. the average values of 1995 and 1996, two 'normal' years.

Sales orientation

Sales orientation is proxied by plant export propensity (EXP). For plant $i$, it is defined as the ratio of exports to total output

$$
E X P_{i}=\frac{E X_{i}}{\text { Output }_{i}}
$$


where $E X_{i}$ is export of plant $i . E X_{i}$ is estimated by multiplying the percentage of exported output in production (i.e. PRPREX in SI data) by the value of output.

\section{Ownership}

Two types of variables were created for firm ownership: continuous and dummy ownership variables. A continuous ownership variable was created for every plant $i$ : the percentage share of foreign ownership $\left(F O R_{i}\right)$. Three dummy variables were created for every plant $i$ : domestic-private $\left(D P R I_{i}\right)$, foreign $\left(D F O R_{i}\right)$ and state-owned plants $\left(D G O V_{i}\right) . D P R I_{i}$ and $D F O R_{i}$ are defined as

$D_{P R I_{i}}\left\{\begin{aligned}=1 & \text { if the share of domestic-private ownership in } \\ & \text { plant } i \text { is equal to } 100 \text { per cent } \\ = & 0 \text { otherwise. }\end{aligned}\right.$

$\operatorname{DFOR}_{i}\left\{\begin{array}{l}=1 \text { if } F O R_{i}>0 \text { per cent } \\ =0 \text { otherwise. }\end{array}\right.$

Joint venture plants require special treatment and assumptions. Three joint venture groups of plants, foreign-government, foreign-domestic and foreigngovernment-domestic, are considered foreign plants (i.e. $D F O R_{i}=1$ ). This classification is based on previous empirical studies which show that foreign partners are dominant, particularly on matters related to finance and technology, even when they are minority shareholders (see for example Aswicahyono and Hill, 1995; Ramstetter, 1999).

In the case of state-owned plants, and following a similar argument as for $D F O R_{i}$, the government-domestic group is classified as 'government' and hence, $D G O V_{i}$ is defined as

$\operatorname{DGOV}_{i}\left\{\begin{array}{l}=1 \text { if } G O V_{i}>0 \text { per cent } \\ =0 \text { otherwise. }\end{array}\right.$

Size

Size $\left(S I Z E_{i}\right)$ is proxied by number of employees. The other common alternatives, such as output or profits, are not used as they tend to be more sensitive to changes in the business cycle, a factor of particular significance in 
this study. ${ }^{18}$ An employment based measure also avoids index number problems associated with deflating output values, an important consideration in times of very high inflation.

Factor intensity

We employ dummy variables based on an industry classification defined by Ariff and Hill (1985) to measure factor intensity at industry level: resourceintensive $\left(D R I_{j}\right)$, labour-intensive $\left(D L I_{j}\right)$ and capital-intensive industries $\left(D C I_{j}\right)$. For industry $j$, which is defined at the four-digit ISIC level,

$D R I_{j}\left\{\begin{array}{r}=1 \text { if industry } j \text { is classified as a } \\ \text { resource-intensive industry. } \\ =0 \text { otherwise. }\end{array}\right.$

$D L I_{j}\left\{\begin{array}{l}=1 \text { if industry } j \text { is classified as an unskilled labour-intensive } \\ \quad \text { industry. } \\ =0 \text { otherwise }\end{array}\right.$

$D C I_{j}\left\{\begin{array}{l}=1 \text { if industry } j \text { is classified as a } \\ \text { capital-intensive industry } \\ =0 \text { otherwise }\end{array}\right.$

${ }^{18}$ See for example Domowitz et al. (1986) and Rotemberg and Saloner (1986). 